ARTICLE

\title{
An Empirical Study on the Effects of Social Endowment Insurance Reform in China
}

\section{Yuhao Cheng*}

Yokohama National University, Yokohama, 240-8501, Japan

\begin{tabular}{l}
\hline ARTICLE INFO \\
\hline Article history \\
Received: 26 June 2019 \\
Revised: 30 June 2019 \\
Accepted: 24 October 2019 \\
Published Online: 31 October 2019 \\
\hline
\end{tabular}

Keywords:

DID model

China social endowment insurance

\section{Introduction}

hinese social endowment insurance Faced with a huge problem. it was difficult to guarantee life after retirement. ${ }^{[1]}$

In 2000, the Chinese government prepares to reform social endowment insurance, and the insurance system of China was changed from the enterprise based endowment insurance to the social compulsory endowment insurance. In December 2000, the State Council of China announced the "Notice on improving the social insurance system". According to this notice, social endowment insurance premiums for each individual were transferred to an individual exclusive account and social insurance fund. Abuse of the social insurance fund was prohibited. And the insurance premiums in the personal account can be used only as for the retirement allowance after retirement. If an in-

\section{ABSTRACT}

In recent years, China, the world's largest population country, has also become an aging society. Social endowment insurance is not only a major source of income after retirement but also plays a major role in social stability. In 2005, large-scale social endowment insurance reform was conducted in China. Through this reform, the social endowment insurance became unified and normalized, and the participation of the social endowment insurance was obligated for an employee. In addition, the government has issued various welfare policies so that the unemployed, free job and rural residents can join social endowment insurance. Then, this paper analyzes the effect of the reform of China social endowment insurance on the amount of Insurance premium of social endowment insurance and the distribution of family expenditure by using the DID model and the fixed effect model.

sured person dies, the amount remaining in an individual account can be inherited as a legacy.

Liaoning province of China was the first to carry out the social insurance reform as the practice place.

\subsection{Main Policy}

The main policies of the reform were

(1) All the employees of all enterprises (including foreign and private companies) were obligated to participate in the social endowment insurance. The insurance premiums are $28 \%$ of the basic wages. Employees pay $8 \%$ of the basic wages, and the companies will pay $20 \%$ of their basic wages.

(2) The local government and the central government will afford allowances to urge the unemployed, free job to join the social endowment insurance. 
(3) The local government, the central government, and the welfare institution will afford allowances to urge rural residents to join social endowment insurance.

The main purpose of these policies is to create a social endowment insurance system that could cover all Chinese people. ${ }^{[2]}$

\subsection{Type of Social Endowment Insurance}

There are mainly three kinds of social endowment insurance after the reform of social endowment insurance. ${ }^{[3]}$

(1) Staff Basic Endowment Insurance: It is compulsory for all corporate staff members to have a staff basic endowment insurance. The insurance premiums are composed of $8 \%$ of the basic wage paid by individual employees and $20 \%$ of the basic wage paid by companies. Together it is $28 \%$ of the basic staff wage. The individual's burden goes to individual exclusive accounts, and the company's burden goes to the social insurance fund. After the staff retired, they will receive a pension every month.

Pension $=$ basic pension + individual account pension

The basic pension is paid from the social insurance fund and determined by the social average wage in retirement year and the weighted average wage of the individual and the number of years of payment.

Basic pension $=0.5$ ( social average wage + the weighted average wage of the individual) $\times$ years of payment $\times 1 \%$

The individual account pension is paid from the individual exclusive account. If the individual exclusive account runs out, and the insured person is alive, the social insurance fund will pay instead. If an insured person dies before the individual exclusive account runs out, the amount left in an individual exclusive account can be inherited as a legacy.

Individual account pension $=$ the amount in individual exclusive account/calculation month

The calculation month varies according to the age of retirement. (for example, if the retirement age is 60 years old, the calculation month is 139 ; if the retirement age is 65 years, calculation month is 101; and if the retirement age is 70 years old, calculation month is 56).

(2) Urban residents social endowment insurance: the unemployed, self-employed person and free job who live in a town can join urban residents social endowment insurance. The insurance premiums are divided into 12 levels from 100 yuan to 2000 yuan every year. Urban residents choose their level and pay insurance premiums. The amount of payment is deposited in the individual exclu- sive account totally. The central government will grant the same amount of subsidies to insured persons who live in the central and western areas of China and grant the subsidies as $50 \%$ of the premiums to those who live in the eastern region. Local governments will grant subsidies more than 30 yuan annually according to their personal finances to insured persons. All subsidiaries shall be transferred to the individual exclusive account along with personal premiums. When the insured person exceeds 60 years old, they begin to receive a pension.

Pension=basic pension + individual account pension

(3) New rural area residents endowment insurance: rural area residents can join the new rural area residents endowment insurance. The insurance premiums are divided into five levels: 100 yuan, 200 yuan, 300 yuan, 400 yuan, 500 yuan each year. Individuals choose from them and pay the insurance premium. All the amount of payment is deposited in the individual exclusive account. The central government will grant the same amount of subsidies to insured persons who live in the central and western areas of China and grant the subsidies as $50 \%$ of the premiums to those who live in the eastern region. Local governments will grant subsidies more than 30 yuan annually according to their personal finances to insured persons. The Rural Committee also actively grant subsidies according to the situation. When the insured person exceeds 60 years old, they begin to receive a pension. The method of calculating the pension and payment is the same as the urban resident's social endowment insurance.

\subsection{The Result of the Reform}

Five years after the practice of Liaoning Province, 2005 year the central government began the reform of social endowment insurance among the whole country. ${ }^{[4]}$ The local government strictly supervises the social endowment insurance fund and grants subsidies actively according to the situation.

The central government and the local government have issued a various policy to complete the social endowment insurance system. The management and operation of the social endowment insurance fund also became more strictly.

There are two main changes in the reform of social endowment insurance in 2005. One is that social endowment insurance has become compulsory and normalized, and another is that the central government and local governments have started assistance subsidies in social endowment insurance. ${ }^{[5]}$

In China, the world's largest population, it is needless 
to say that the importance of social endowment insurance. ${ }^{[2]}$ However, how much does the reform of social endowment insurance affect the welfare of the people? And, how does social endowment insurance affect the distribution, consumption, and savings of family? The purpose of this study is to confirm the effect and influence of the reform of China social endowment insurance in 2005 .

\section{Literature}

Modigliani and Brumberg (1954) build the life cycle theory, people live in two periods. It is a young saving period and an old consumption period. Everyone acts to maximize the utility in the two periods. There is an alternative relationship between social endowment insurance and savings, and it is shown that compulsory social endowment insurance affects household savings.

Y Zhigang and S Zheng (2000) made the OLG model and proved that the social endowment insurance system affects consumption. It also insisted that the decrease in the labor force in the future would surely affect consumption and savings. ${ }^{[6]}$

Y Zhigang (2001) analyzed the Chinese macroeconomy and said it was difficult to guarantee life after retirement because of the low interest rate of the current social insurance account. This also lowered the willingness to join social endowment insurance. ${ }^{[1]}$

Liu Jun (2004) analyzed the proportion of China social insurance (including medical insurance) to income through an econometric model. Liu thinks the optimum ratio is $15 \%{ }^{[7]}$

Qiu Changrong, Zhang Li guang and Guo yan (2004) rated China social endowment insurance system. through the metric model, it has been found that there is a serious problem in the management of the social endowment insurance fund and the distribution between generations before the reform. To solve this problem is one of the important causes of the reform. ${ }^{[8]}$

Peng Haoran and Shen Shuguang (2007) analyzed the relationship between income and social endowment insurance. The theoretical model shows that there is a strong positive correlation between social endowment insurance and the income when a person has a low income, and the correlation becomes low when the income becomes high. ${ }^{[2]}$

Ning YU, Qinghua SHI and Hongtao JIN (2010) through OLG models, has proven that there is an alternative relationship between social endowment insurance and the ownership of the house and land. It was proven that the willingness of them having a house or land to join the social endowment insurance was lower than the person without the ownership. ${ }^{[4]}$

Liu Ao (2011) explained the cause and history of the China social endowment insurance reform, and explain the scale and the present state of insurance in detail. He also pointed out the problem and the direction of reform in each stage.

Previous research has not analyzed by the DID model when confirming the effect of China social insurance reform. Therefore, this paper examines the effect of the reform of social endowment insurance. Especially paying attention to the change of the insurance premiums before and after the reform. In addition, based on the data of the stable period of social insurance, the fixed effect model is used to verify the relationship between home income and social endowment insurance premiums.

\section{Data}

The data used in this study are the Chinese household survey (UHS). UHS was conducted by the China National Statistics Bureau. The survey covers 49 provinces in China. The sample of the survey is the family living in Chinese urban. The survey includes household income (wages, investment income), consumption, savings, taxes, and insurance premiums. It also included family members' occupations and household property.

UHS is held every year. One family is surveyed for three consecutive years and the one-third sample is changed every year. Since two-thirds of the sample in two consecutive years will be panel data, this study will focus on two-thirds of these samples and avoid the bias inherent in a home.

\subsection{Selection of Sample}

There are three types of social endowment insurance in China, but the types of social endowment insurance which people can join is depended on the family register and occupation. The sample is divided by the occupation to measure the effect of the staff basic endowment insurance and the urban residents' social endowment insurance. However, there is no sample of rural residents in UHS.

The insurance premiums of the staff basic endowment insurance are depended on the wage. Using staff family samples can show whether the reform made the social endowment insurance system normalization and compulsion.

And the insurance premiums of the urban residents' social endowment insurance is decided by the individual, using the unemployed, self-employed person and free job family data the effect of the assistance and subsidies 
can be understood.

The data in 2004, 2005, 2008 and 2009 were used. In 2000, the Liaoning province took the first, and since 2005, China all provinces started the reform of the social endowment insurance. Using the 2004 and 2005 data, we can see the effect of the reform of social endowment insurance. In addition, the scope of social endowment insurance basically covered all adult people after three years in 2008. Social endowment insurance has stabilized. Using the data in 2008 and 2009, we can see the relationship between household income and social endowment insurance premiums.

The number of samples in 2004 and 2005 is 32811. Among its 8394 are unemployed, self-employed or free job families. In this home, there are people who join the urban residents' social endowment. There are 24308 staff families. There are people who join the staff basic endowment insurance in these homes.

The number of samples in 2008 and 2009 is 18166. among them, 9419 families were continuously surveyed in 2008 and 2009. The number of staff family is 5739, and the number of unemployed, self-employed or free job families is 3218 .

\subsection{Common Trends}

DID model can be used when the experimental group and conditional group have a common trend. ${ }^{[9]}$ We take the average insurance premium from 2002 to 2009 to check the common trends between the experimental group and the conditional group.

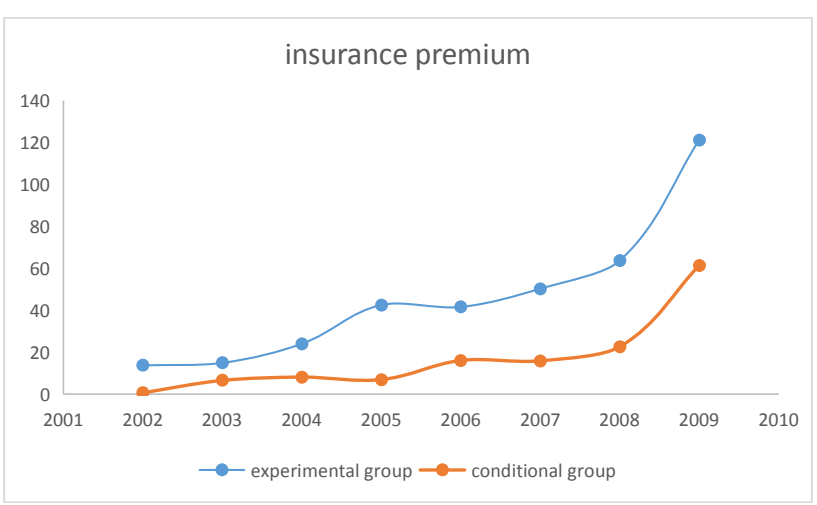

Figure 1

Figure 1 shows the average insurance premiums in the experimental group and conditional group. It can be easy to see the common trends and the difference in the year of reform.

Except for the insurance premium, we also check whether there are common trends in the family's incoming, consumption, saving and investment.

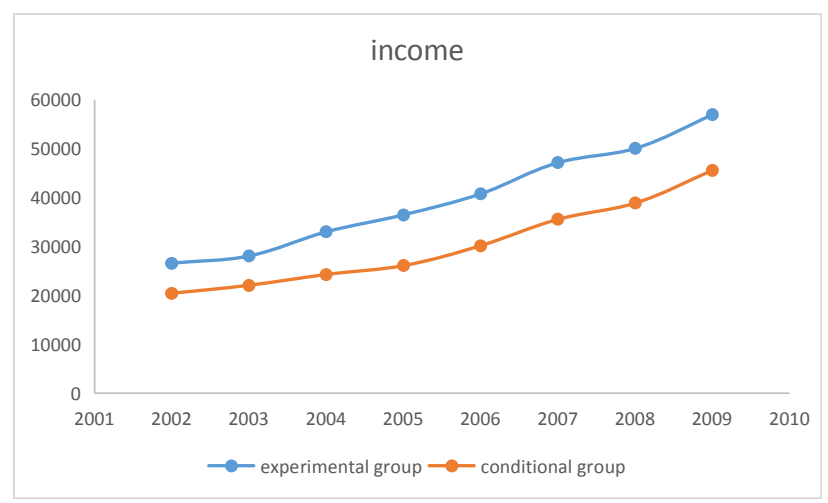

Figure 2

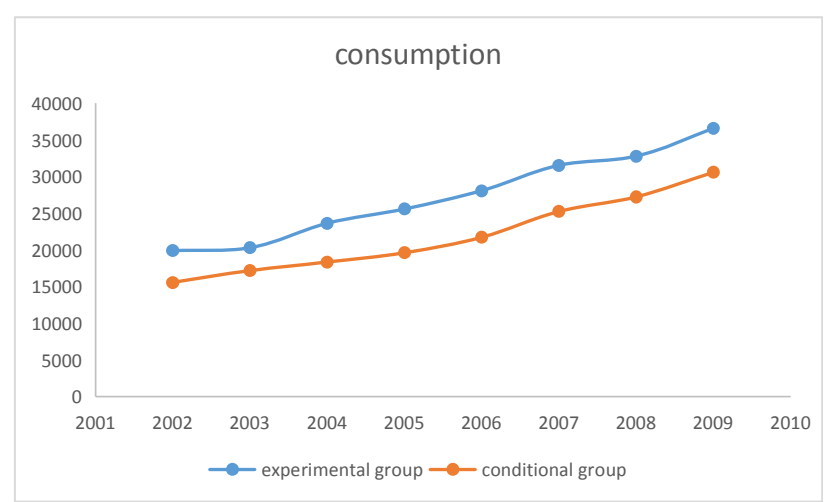

Figure 3

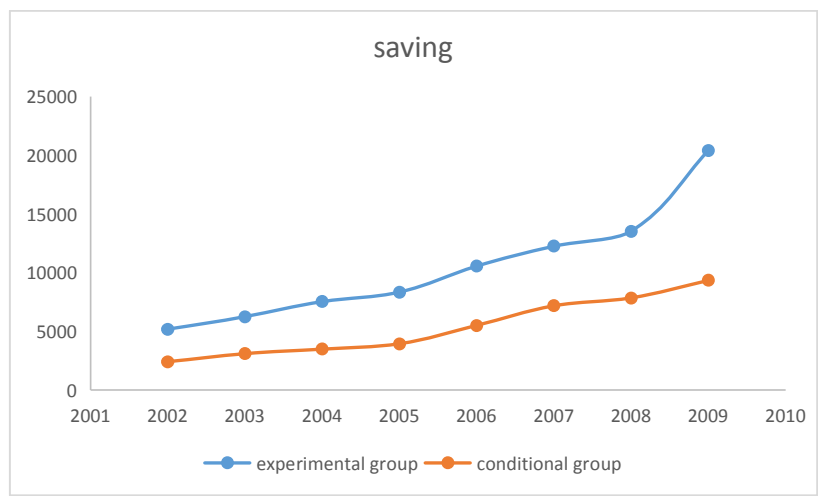

Figure 4

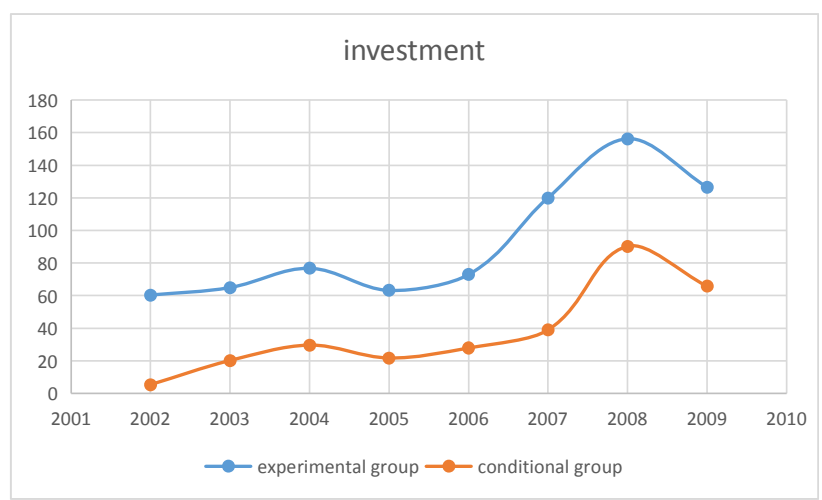

Figure 5 
From Figure 2 to Figure 5, there is an obvious common trend during experimental group and conditional group.

\section{Empirical Equation}

We used the 2004 and 2005 data to make the DID model for testing the effect of the reform of social endowment insurance and use 2008 and 2009 data to check the relationship between household income and social endowment insurance premiums.

\subsection{The effect of the reform}

Here we analyze the effects of policy using the 2004 and 2005 data. The DID model is made by using the difference of time and the difference of the execution region. The empirical equation is:

$$
\text { insurance }_{i t}=\alpha_{1} T+\alpha_{2} D+\beta(T \cdot D)+\delta X_{t}+\varepsilon_{i}
$$

Insurance is the amount of social endowment insurance premiums paid by the family $\mathrm{i}$ at the year $\mathrm{t}$. $\mathrm{T}$ is a year dummy variable.

$$
T=\left\{\begin{array}{cc}
1 & 2004(\text { before the reform }) \\
0 & 2005(\text { after the reform })
\end{array}\right.
$$

$\mathrm{D}$ is a local dummy variable. Since the Liaoning province had taken the reform in 2000, the reform in 2005 Liaoning province became a control group.

$$
D= \begin{cases}1 & \text { others province }(\text { experimenth group) } \\ 0 & \text { Liaoning province (conditional group) }\end{cases}
$$

$\mathrm{X}_{\mathrm{it}}$ is a control variable (family size, income, etc.) when

\begin{tabular}{|c|c|c|c|c|}
\hline Outcome var. & insur e & S. Err. & $|\mathrm{t}|$ & $P>|t|$ \\
\hline \multicolumn{5}{|l|}{ Before } \\
\hline Control & 792.897 & & & \\
\hline Treated & 896.432 & & & \\
\hline $\operatorname{Diff}(\mathrm{T}-\mathrm{C})$ & 103.535 & 32.219 & 3.21 & $0.001 * * *$ \\
\hline \multicolumn{5}{|l|}{ After } \\
\hline Control & 774.907 & & & \\
\hline Treated & 1006.963 & & & \\
\hline $\operatorname{Diff}(\mathrm{T}-\mathrm{C})$ & 232.056 & 31.466 & 7.37 & $0.000 * * *$ \\
\hline Diff-in-Diff & 128.521 & 45.035 & 2.85 & $0.004 * * *$ \\
\hline
\end{tabular}
the family $i$ in time t. $\beta$ is the effect of the reform of social endowment insurance.

Figure 6

From Figure 6, the amount of social endowment insurance premiums increases about 128 yuan after the reform. In general, the reform promoted social endowment insur- ance, and the insurance premiums increased.

The type of social endowment insurance which individuals join is different depending on the occupation of the individual. Limit the sample, we can test the normaliza-

\begin{tabular}{|c|c|c|c|c|}
\hline Outcome var. & insur e & S. Err. & $|t|$ & $P>|t|$ \\
\hline \multicolumn{5}{|l|}{ Before } \\
\hline Control & 1058.950 & & & \\
\hline Treated & 1083.744 & & & \\
\hline $\operatorname{Diff}(\mathrm{T}-\mathrm{C})$ & 24.794 & 40.245 & 0.62 & 0.538 \\
\hline \multicolumn{5}{|l|}{ After } \\
\hline Control & 1061.302 & & & \\
\hline Treated & 1243.284 & & & \\
\hline $\operatorname{Diff}(\mathrm{T}-\mathrm{C})$ & 181.982 & 40.874 & 4.45 & $0.000 * * *$ \\
\hline Diff-in-Diff & 157.188 & 57.362 & 2.74 & $0.006 * \pi *$ \\
\hline
\end{tabular}
tion and compulsion after the reform, and check the effect of subsidies.

\begin{tabular}{|c|c|c|c|c|}
\hline Outcome var. & insur e & S. Err. & $|t|$ & $P>|t|$ \\
\hline \multicolumn{5}{|l|}{ Before } \\
\hline Control & 714.378 & & & \\
\hline Treated & 758.338 & & & \\
\hline $\operatorname{Diff}(T-C)$ & 43.960 & 53.938 & 0.82 & 0.415 \\
\hline \multicolumn{5}{|l|}{ After } \\
\hline Control & 677.386 & & & \\
\hline Treated & 900.820 & & & \\
\hline $\operatorname{Diff}(\mathbb{T}-\mathrm{C})$ & 223.434 & 50.809 & 4.40 & $0.000 * * *$ \\
\hline Diff-in-Diff & 179.474 & 74.100 & 2.42 & $0.015 * *$ \\
\hline
\end{tabular}

Figure 7

Figure 8

The samples used in Figure 6 are the staff families. There are families that join the staff basic endowment insurance. The effect showed in Figure 7 represents the normalization and compulsion of the social endowment insurance.

The samples used in Figure 8 are the unemployed, self-employed and free job families. In other words, there are families that join the urban residents' social endowment insurance. The effect showed in Figure 8 shows the effect of government policy and subsidies.

Social endowment insurance reform not only affects the social endowment insurance premiums, household expenditure but also changes.

$$
\mathrm{Y}_{i t}=\lambda+\lambda_{1} T+\lambda_{2} D+\gamma(T \cdot D)+\varphi X_{i}
$$

$\mathrm{Y}_{\mathrm{it}}$ is families expenditure content consumption, savings, savings insurance, bonds and investment in the family at the time $t$. 


\begin{tabular}{|c|c|c|c|c|c|}
\hline VARIABLES & $\begin{array}{c}\text { (1) } \\
\text { consumption }\end{array}$ & $\begin{array}{l}\text { (2) } \\
\text { saving }\end{array}$ & $\begin{array}{c}\text { (3) } \\
\text { saving_insurance }\end{array}$ & $\begin{array}{l}\text { (4) } \\
\text { bond }\end{array}$ & $\begin{array}{c}\text { (5) } \\
\text { investment }\end{array}$ \\
\hline $\mathrm{T}$ & 252.2 & $\begin{array}{l}-296.9 \\
(372.8)\end{array}$ & $\begin{array}{l}-10.99 \\
56.6309\end{array}$ & $\begin{array}{l}-40.85 \\
010977\end{array}$ & $172.0^{* * *}$ \\
\hline D & 355.6 & $574.3^{* 0}$ & $111.3^{\circ *}$ & -10.34 & 4.425 \\
\hline & (333.7) & $(289.3)$ & (43.69) & $(85,11)$ & (63.61) \\
\hline $\mathrm{DID}$ & $\begin{array}{l}-156.5 \\
(464.6)\end{array}$ & $\begin{array}{r}-329.5 \\
(402.8)\end{array}$ & $\begin{array}{l}-72.31 \\
(60.83)\end{array}$ & $\begin{array}{l}-41.82 \\
(118.5)\end{array}$ & $\begin{array}{l}-203.20 * \\
(88.57)\end{array}$ \\
\hline income & $\begin{array}{l}0.553^{* * * *} \\
(0.00335)\end{array}$ & $\begin{array}{l}0.406^{* * * *} \\
(0.00291)\end{array}$ & $\begin{array}{l}0.0159^{* * *} \\
(0.000439)\end{array}$ & $\begin{array}{l}0.0160^{* * * *} \\
(0.000855)\end{array}$ & $\begin{array}{l}0.00503 * * * \\
(0.000639)\end{array}$ \\
\hline family_member & $\begin{array}{c}1,1310 \cdots \\
(102,7)\end{array}$ & $\begin{array}{c}-954,7 \ldots 6 \\
(89.06)\end{array}$ & $\begin{array}{l}-25.45^{\circ} \\
(13.45)\end{array}$ & $\begin{array}{c}-55.910 * \\
(26.20)\end{array}$ & $\begin{array}{l}-12.96 \\
(19.58)\end{array}$ \\
\hline Constant & $\begin{array}{l}1.681^{* * *} \\
(427.6)\end{array}$ & $\begin{array}{c}-3,603^{* * * *} \\
(370.7)\end{array}$ & $\begin{array}{l}-136.6^{* * *} \\
(55.98)\end{array}$ & $\begin{array}{l}-174.4 \\
(109.1)\end{array}$ & $\begin{array}{l}-54.99 \\
(81.51)\end{array}$ \\
\hline Observations & 32,810 & 32,810 & 32,810 & 32,810 & 32,810 \\
\hline R-squared & 0.468 & 0.379 & 0.040 & 0.011 & 0.002 \\
\hline
\end{tabular}

Figure 9

From Figure 9, it is the only investment that gets a significant influence by the reform of social endowment insurance. After this reform of the social endowment insurance, people are desirable for the safety property and the reform had a negative effect on the investment. And, since it does not have a significant influence on consumption, the reform of the social endowment insurance is not able to lower the home utility level. The main reason is that the percentage of the social endowment insurance premiums to the total income of the family is low.

\subsection{Relationship between Household Income and Social Endowment Insurance Premiums}

More than $95 \%$ of adult people join the social endowment insurance. social endowment insurance has reached a stable period. The estimation equation of the social allowance for the aged and the retirement rate of the household income is as follows.

$$
\text { insurance }_{i t}=\alpha+\beta \text { icome }_{i t}+\delta X_{t}+\lambda P_{i}
$$

Here insurance is the amount of social endowment insurance premiums that family I pay at the time t. Income $_{i t}$ is the income of the family I at the time $t . X_{i t}$ are the control variables when the family I at the time $t$. $\mathrm{P}$ is the family fixed effect. The fixed effect model is used to estimate the $\beta$ which represents the relationship between household income and social endowment insurance premiums.

$$
\text { insurance }_{i}=\alpha+\beta \Delta \text { icome }_{i}+\delta \Delta X_{i}
$$

$\Delta$ insurance $_{i}$ is the difference in social endowment insurance premiums between 2008 and 2009. $\Delta$ icome $_{i}$ is the difference in income between 2008 and 2009. $\Delta X_{i}$ is the difference in control variables between 2008 and 2009 .

\begin{tabular}{r|rcrrrr}
\hline insurance & Coef. & Std. Err. & $t$ & $p>\mid t$ ) & \multicolumn{1}{c}{ [95? Conf. Interva1] } \\
\hline income & .0128512 & .0021035 & 6.11 & 0.000 & .0087267 & .0169757 \\
investment & -.0000796 & .0051838 & -0.02 & 0.988 & -.0102437 & .0100846 \\
saving & -.004181 & .0022227 & -1.88 & 0.060 & -.0085392 & .0001772 \\
cons & 1030.553 & 82.2452 & 12.53 & 0.000 & 869.2898 & 1191.816 \\
\hline sigma_u & 2018.8669 & & & & & \\
sigma_e & 1478.6626 & & & & & \\
rho & .65085437 & (fraction of variance due to u_i) & \\
\hline
\end{tabular}

Figure 10

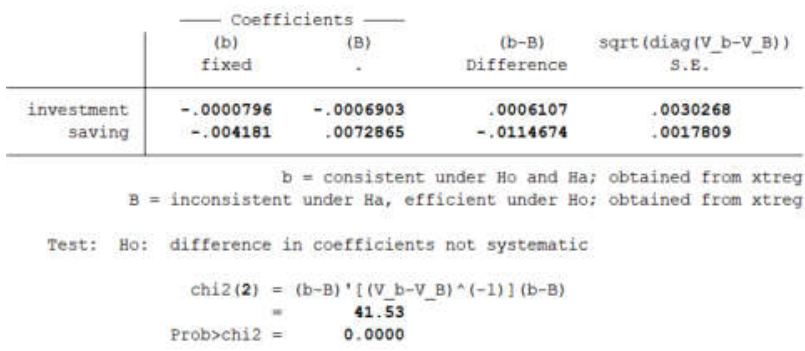

Figure 11

Figure 10 is made up of data from the unemployed, self-employed, and free job families because premiums of the staff basic endowment insurance are determined by wages, and the unemployed, self-employed and free job families can select the premiums' level freely. In this part, we only use data from the unemployed, self-employed, and free job families. As shown in Figure 5, when the income increases by one yuan, the social endowment insurance premiums increase by about 0.013 yuan.

Figure 11 shows the result of the Hausman test. The fixed effect model is better than the random effect model.

Because the upper limit of the insurance premiums of the urban residents' social endowment is 2000 yuan, there is an upper limit for the amount of pension after retirement. The security of the life that the wealthy layer gets from the social endowment insurance system is limited. The relationship between social endowment insurance premiums and income depends on income. According to income, the sample is divided into four, and the metric analysis function is that:

$$
\text { insurance }_{i}=\alpha+\sum_{j=1}^{4} \beta_{\mathrm{j}} \Delta\left(\text { income }_{i} \times \mathrm{D}_{\mathrm{j}}\right)+\lambda \Delta X_{i}
$$

$\mathrm{D}_{\mathrm{J}}$ is a quadrature dummy variable. Using quadrilateral dummy variables, income is divided into four levels. In other words, the family belonging to the first rank is the poorest, and the family belonging to the fourth rank is the wealthiest.

$$
D_{j}= \begin{cases}1 & \text { family belong to } \mathrm{j} \text { quadrature }(j=1,2,3,4) \\ 0 & \text { others }\end{cases}
$$


Income $_{\mathrm{j}} \times \mathrm{DJ}$ is a quadrature dummy variable multiple incomes. Here, four parameters from $\beta 1$ to $\beta 4$ are the effects of household income of each wealthy class on social endowment insurance premiums.

\begin{tabular}{r|rrrrrr}
\hline insurance & Coef. & std. Err. & $t$ & P $>|t|$ & \multicolumn{1}{c}{ [95\% Conf. Interva1] } \\
\hline income_D1 & .0061516 & .0075507 & 0.81 & 0.415 & -.0086535 & .0209567 \\
income_D2 & .0110506 & .0049423 & 2.24 & 0.025 & .0013599 & .0207413 \\
income_D3 & .0168458 & .0035063 & 4.80 & 0.000 & .0099708 & .0237209 \\
income_D4 & .0121141 & .0021816 & 5.55 & 0.000 & .0078366 & .0163917 \\
investment & -.0001494 & .005184 & -0.03 & 0.977 & -.0103139 & .010015 \\
saving & -.0037338 & .0022256 & -1.68 & 0.094 & -.0080976 & .00063 \\
_cons & 1052.602 & 138.2246 & 7.62 & 0.000 & 781.5769 & 1323.628 \\
\hline sigma_u & 2010.7398 & & & & & \\
sigma_e & 1476.9918 & & & & \\
rho & .64953376 & (fraction of variance due to u_i) & \\
\hline
\end{tabular}

Figure 12

As seen from Figure 12, the effect of family income on social endowment insurance premium varies according to income. Even if the income of a poor family increases, it does not have a big change in the social endowment insurance premium. Because the consumption increases first when the income of poor households increases. In middle-income households, when income increases social endowment insurance premium increases obviously. However, the impact of this income tends to be lower in higher income families

\section{Conclusion}

By the analysis using the DID model, it was proven that the effect of the reform of the endowment insurance was remarkable. After the reform, an increase in social endowment insurance premiums occurred. Insurance premiums increase, but there is no decrease in consumption and savings. In addition, it was also clarified that the living security of the people after they retire has been guaranteed and there is no evidence that could prove that the social endowment insurance adds to the family's burden.

In addition, the effect of social insurance was found to differ according to individual income. It was also proven that there is a strong relationship between the social endowment insurance premium and family income in middle and high-income families.

\section{References}

[1] YANG Zhigang (2001). Analysis of the selection of China social endowment insurance system[J]. Economic Research Journal, 2001(5):13-19.

[2] PENG Horan \& Shen Shuguang (2007). A comparative study on the effects of endowment insurance system on income redistribution before and after the reform in China[J]. Statistical Research, 2007, 24(2):33-37.

[3] ZHENG Bingwen (2003). Nominal account: a rational choice of China's endowment insurance[J]. Management World, 2003(8):33-65.

[4] Ning YU, Qinghua SHI \& Hongtao JIN (2010). Permanent land-use rights and endowment insurance: Chinese evidence of the substitution effect[J]. China Economy Review, 2010(21):272-281.

[5] ZHANG Yugang (2005). Aging of population and China's endowment insurance system reform[J]. Journal of Sichuan Normal University, 2005, 32(2):18-23.

[6] Yuan Zhigang \& Song Zheng (2000). Age composition of population, the endowment insurance system and optimal savings ratio in china[J] Economic Research Journal, 2000(11):24-79.

[7] LIU Jun (2004). The determination of social insurance contribution a theoretical and empirical analysis[J]. Journal of Finance and Economics, 2004, 30(2):73-79.

[8] QIU Changrong, ZHANG Liguang \& GUO Yan (2004). Research on the comprehensive evaluation system of sustainable social endowment insurance and empirical analysis[J]. China Population, Resources And Environment 2004, 14(3):27-31.

[9] Joshua D. Angrist \& Jorn Steffen Pischke (2008). Mostly Harmless Econometrics: An Empiricist's Companion[M]. Princeton University Press, 165-167. 